\title{
A Polgári jog. Kommentár a gyakorlat számára I-III.
}

\section{Commentary on Civil Code for Practitioners Vol. I-III.}

ÖsSZEFOGLALÁs

A Polgári Törvénykönyvrôl szóló 2013. évi V. törvényt 2013. február 11-én fogadta el az Országgyúlés, és 2014. március 15-én lépett hatályba. A szerzók kifejezett érdeme, hogy a háromkötetes törvénymagyarázatot elsố ízben már 2013-ban megjelentették, így a jogkeresố közönség már a törvény hatálybalépése elôtt kedvére forgathatta a kommentárt. Célunk alapvetôen a kommentár szerkezetének és szerzóinek bemutatása és erényeinek kidomborítása.

Kulcsszavak: joggyakorlat, kommentár, polgári jog, recenzió

\section{SUMMARY}

Act V of 2013 on the Civil Code of Hungary was adopted on 11 February 2013 by the National Assembly and it entered into force on 15 March 2014. As for the first time, the three-volume commentary was published in 2013, inquiring citizens had had the opportunity to use it before the entry into force of the new Civil Code. The review presents the structure and authors of the commentary and emphasizes its merits.

Keywords: commentary, civil law, judicial practice, review

IvÁn DÁNIEL, tanársegéd, Nemzeti Közszolgálati Egyetem, Államtudományi és Közigazgatási Kar, Lőrincz Lajos Közigazgatási Jogi Intézet; doktoranduszhallgató, Nemzeti Közszolgálati Egyetem, Közigazgatás-tudományi Doktori Iskola (Ivan.Daniel@uni-nke.hu), KoI Gyula tudományos munkatárs, Magyar Tudományos Akadémia, Társadalomtudományi Kutatóközpont, Jogtudományi Intézet; tudományos főmunkatárs, Nemzeti Közszolgálati Egyetem, Államtudományi és Közigazgatási Kar, Lórincz Lajos Közigazgatási Jogi Intézet (Koi.Gyula@uni-nke.hu). 
Az új civiljogi kódex (A Polgári Törvénykönyvrôl szóló 2013. évi V. törvény) kommentárja színes szerzói kört vonultat fel, ahol az elmélet múvelối és a gyakorlat ismerôi harmonikus egységet alkotnak. Elöljáróban is szükséges utalni arra, hogy az új magyar Ptk. rendeltetése hasonlatos a nagy európai magánjogi kódexek rendeltetéséhez: ezen törvénykönyvek a magánszemélyek, a jogi személyek, továbbá az egyes jogi személyiséggel nem rendelkezô más szervezetek személyi és vagyoni viszonyait foglalják össze.

A kommentár esetében elméleti oldalról a megalkotásában részt vettek: a Magyar Tudományos Akadémia tagjai, ${ }^{1}$ a Magyar Tudományos Akadémia doktorai $(\mathrm{DSc}),{ }^{2}$ az egyetemi professzori kar tagjai, ${ }^{3}$ illetve egyes egyetemi docensek, ${ }^{4}$ valamint más elméleti múvelôk. ${ }^{5} \mathrm{~A}$ kommentár gazdagításában számos gyakorlati szakember vett részt. ${ }^{6}$

A Polgári Törvénykönyv helyét és szerepét jól mutatja a kommentár kodifikációtörténeti alapozása. ${ }^{7}$ Nagyon jellegzetes az a megfogalmazás, amely szerint 1959-ig terjedôen tizenegy kodifikációs kísérlet sem hozott törvénykönyvben manifesztálódó eredményt (az 1486. évi, az 1498. évi, az 1500. évi, az 1514. évi, az 1848. évi, az 1900. évi, az 1905. évi, az 1913. évi, az 1915. évi, valamint az 1928. évi törekvések). A kommentár szerzói I. (Hunyadi) Mátyás királyt tartják a magyar igazságszolgáltatás ${ }^{8}$ elsố korai reformerének. Az 1486. évben kelt Decretum maius nevet viselố rendeletével széles értelemben vett polgári jogi törvényhozást kezdeményezett. 1498-ban a rendek felhatalmazására Horváth Ádám ítélômester egybegyújtötte a perjogi természetú régi szokásjogi szabályanyagot. A szintén a szokásjog összegyújtésére vonatkozó, a nyol- cados törvényszék választott ülnökeinek adott országgyúlési megbízás eredménytelen maradt (1500. évi X. törvénycikk). II. Ulászló a rendek sürgetésére Werbôczy Istvánt bízta meg a szokásjog összegyújtésével. A Kommentár szerzőinek meggyóződése szerint a megbízás pontos idôpontja nem ismert, de Werbốczy már jóval korábban dolgozott szokásjogi jogkönyve megalkotásán. ${ }^{9}$ A Hármaskönyv szerkesztésében Werbő́czy segítségére voltak ítélômester kollégái, valamint a királyi törvényszék ülnökei, akiket erre királyi utasítás kötelezett. 1514-re készült el a Hármaskönyv szövege, melyet Werbôczy benyújtott az Országgyúlésnek megvizsgálás végett. Az erre felkért országygyúlési bizottság jelentette, hogy munka az ország szokásjogával megegyezik, és felkérték a királyt, hogy hagyja jóvá a jogkönyvet, pecsétjével erôsítse meg, és küldje meg a vármegyéknek kihirdetés végett, amivel az törvényerôre emelkedett volna. A király hamarosan ünnepélyes oklevéllel megerôsítette a Hármaskönyvet, kijelentvén, hogy tartalma az ország jogaival és szokásával megegyezik, és elrendelte, hogy érvényes jog és törvény gyanánt fogadják el azt. A király jelezte az Országygyúlés számára, hogy a könyvet megküldi a megyéknek, ami azonban nem történt meg, és így az nem emelkedett törvényerôre (a pontos okok nem ismertek, a legenda szerint a fốnemesi párt hiúsította meg a királyi tervet. Mivel ekkor a Hármaskönyv még csak kézirati formában létezett, a másolással foglalkozó írnokokat utasították a munkalassításra, így az opus nem lett annyi példányban lemásolva, hogy valamennyi vármegye hozzájuthasson. Illetve van olyan meggyốzódés, mely szerint a király elốl még a szentesítésre szolgáló pecsétet is elrejtették a fốneme- 
si párt tagjai). Ez is oka volt annak, hogy Werbốczy más úton kívánta biztosítani mûve terjesztését, ezért 1517-ben, Bécsben, latin nyelven Johann Singreiner (Johannes Singrenius) nyomdájában saját kiadásaként megjelentette. A kötet 1565ben magyar, 1574-ben horvát, 1599-ben német fordításban is napvilágot látott, illetve kéziratban késóbb újgörög nyelvre is áttették. Maga a Tripartitum 1628-tól kezdve a Corpus Juris Hungarici része lett, sốt a mú élére helyezték. Rendkívüli elterjedtségét bizonyítja, hogy több mint negyven kiadásban jelent meg a századok során, verses kiadásai is ismertek, és a magyar jogászság lépten-nyomon hivatkozott (és ma is hivatkozik) reá.

Ki kell emelni, hogy a Tripartitum közjogi részeivel együtt a magyar nemesi magánjog szokásjogias kompilációjának tekintendô. Gyakorlatilag Werbốczy múve és a Corpus Juris Hungarici részét alkotó törvények vonzásában fejlődött a hazai magyar magánjog egészen 1848ig (ideértve a werbóczyánus jogi írók ${ }^{10}$ munkásságát is). A reformkori nézetek (különösen Széchenyi István és Deák Ferenc gondolkodása) vezettek oda, hogy az 1848. évi XV. törvénycikk rendelte el az ôsiség teljes és tökéletes eltörlése mellett egy polgári törvénykönyv elkészítését. A korabeli gốzerôvel múködố törvényhozás a Polgári Törvénykönyv megalkotására vonatkozó három hónapos határidôt annak ellenére sem tudta tartani, hogy az igazságügy-miniszter Deák Ferenc, a Törvény-elôkészítố Osztály vezetốje pedig a rendkívüli jogi múveltségú és szinte korlátlan munkabírású jogászakadémikus, Szalay László volt. Az 1900. évi, az 1905. évi, az 1913. évi, az 1915. évi törvényjavaslatokat követte 1928-ban ötödikként Magyarország Magánjogi Törvénykönyvének
Törvényjavaslata (Mtj.). ${ }^{11} \mathrm{Az}$ Mtj. szakmai színvonalát általános elismeréssel illették, számos megoldását a bírói gyakorlat kifejezetten átvette, és szokásjogi úton alkalmazta, ám sajnálatos módon ez az elaborátum sem lett törvénnyé. 1953 decemberében hívta létre az igazságügy-miniszter azt a kormánybizottságot, amely a Polgári Törvénykönyv tervezetének tartalmát megállapította. A javaslat elkészítése során a francia, német és más nyugateurópai polgári törvénykönyvek figyelembevétele mellett, az 1923. évi szovjet polgári törvénykönyv, illetve a magyarral egyidejúleg folyó szovjet kodifikációs munkálatok eredményei mellett az 1950. évi csehszlovák polgári törvénykönyv, az 1955. évi lengyel Ptk.-tervezet, valamint a bolgár 1951. évi tulajdonjogi ${ }^{12}$ törvénybốl építkezett. Magyarország elsô hatályba lépett törvénykönyvét 1959. augusztus 11-én hirdették ki, és 1960. május 1-jétôl lépett hatályba.

Ezt követôen 2010-re alakult ki olyan helyzet, amely afelé mutatott, hogy a korábbi korszak Polgári Törvénykönyvét egy új, modern civiljogi kódexszel szükséges felváltani. A kodifikáció során két szakmai bizottság alakult. A két testület az Operatív Szakmai Bizottság, ${ }^{13}$ valamint a Kodifikációs Szerkesztô Bizottság ${ }^{14}$ volt. Az új Polgári Törvénykönyv javaslatát a KIM 2012. február 15-én társadalmi egyeztetésre bocsátotta. Az új Ptk. megszavazása az Országgyúlésben 2013. február 11-én történt meg. Szükséges utalni arra is, hogy az új Ptk. általános indokolása kiemeli, hogy a kódex nem választ külföldi modellt, hanem bôségesen merít külhoni példákból. Az újabb nemzeti kódexek közül a holland polgári törvénykönyv (Burgerlijk Wetboek) és a kanadai Québec magánjogi kódexe (Code civil du Québec) tekinthetô 
modernek és hatásgyakorlónak is. Mindezzel együtt a törvény a nemzetközi jogalkotás instrumentumaiból is merít. E körben a következóket kell kiemelni: Bécsi Nemzetközi Vételi Egyezmény (Contracts for the International Sale of Goods, 1980), UNIDROIT alapelvek (Principles of International Commercial Contracts, 2010), valamint az európai modellszabályok (Draft of Common Frame of Reference).

A kommentár szerkezete az alapjául szolgáló kódex könyveinek struktúráját követi. A kódex könyvei az alábbiak: Elsố Könyv: Bevezetô rendelkezések; Második Könyv: Az ember mint jogalany; Harmadik Könyv: Jogi személyek; Negyedik Könyv: Családjog; Ötödik Könyv: Dologi jog; Hatodik Könyv: Kötelmi jog; Hetedik Könyv: Öröklési jog; Nyolcadik Könyv: Záró rendelkezések. A kommentár belsô beosztása a lapszámozás tekintetében a Ptk. könyveihez igazodik, azaz az oldalszámok valamennyi könyv esetében elölrôl kezdôdnek, így fordulhat elô, hogy a három kötet esetében nyolcféle oldalszámozás létezik. Az Elsô Könyvet (Bevezetô rendelkezések) Kecskés László elemzi (Petrik, 2013:1-64). A Második Könyvet (Az ember mint jogalany) Kôrös András, Makai Katalin és Petrik Ferenc vizsgálja (Petrik, 2013, I. 1-106). A roppant terjedelmes Harmadik Könyv (Jogi személyek) feldolgozását Boóc Ádám, Gadó Gábor, Gál Judit, Komáromi Gábor, Pázmándi Kinga, Sándor Tamás, Sárközy Tamás, Török Gábor, illetôleg Zsohár András végezte el (Petrik, 2013, I. 1-460). Boros Zsuzsa, Katonáné Pehr Erika, Kôrös András, Makai Katalin, továbbá Szejbert Orsolya írták a Negyedik Könyvet (Családjog) (Petrik, 2013, II. 1-372). Az Ötödik Könyv (Dologi jog) Petrik Ferenc és Pomeisl András munkája
(Petrik, 2013, II. 1-269). A kommentár legterjedelmesebb vállalkozását alkotja a Hatodik Könyv (Kötelmi jog), amely a kötelmi jog általános (ideértve a kontraktuális felelôsséget), továbbá a kötelmi jog különös részét (egyes szerzôdések), illetőleg a felelôsségtant (deliktuális felelôsség) foglalja magában. A könyv szerzói a következők: Bíró György, Farkas Attila László, Fuglinszky Ádám, Harmath Attila, Havasi Péter, Kisfaludi András, Kiss Mária, Kovács László, Kôrös András, Molnár Ambrus, Osztovics András, Petrik Béla, Petrik Ferenc, Pomeisl András, Szejbert Orsolya, Szentiványi Iván, Takáts Péter, Vékás Lajos, Wellmann György (Petrik, 2013, III. 1-970). A Hetedik Könyvet (Öröklési jog) Orosz Árpád kommentálta (Petrik, 2013, III. 1-106). A kommentár utolsó egysége a Nyolcadik Könyv (Záró rendelkezések), mely Osztovits András munkája (Petrik, 2013, III. 1-10).

Meglátásunk szerint a háromkötetes törvénymagyarázat híven szolgálja az új civiljogi kódex megismertetésének nemes feladatát, és ilyen módon bátran ajánljuk mind az elmélettel foglalkozók, mind a joggyakorlat múvelôi, illetve mind a graduális egyetemi képzés, mind a szakjogászi képzések, illetôleg a jogi szakvizsgára készülók széles köre számára.

Petrik Ferenc (szerk.) (2013): Polgári jog. Kommentár a gyakorlat számára I-III. Harmadik kiadás, HVG-Orac, Budapest.

\section{JEGYZETEK}

1 E körben szükséges említenünk Harmathy Attilát, Kecskés Lászlót, valamint Vékás Lajost (utóbbi a Magyar Tudományos Akadémia alelnöke).

2 Itt kell kiemelnünk Sárközy Tamás, Szentiványi Iván, továbbá Török Gábor nevét. 


\section{Tudományos mühely}

3 A szerzốk között találhatóak a következố egyetemi tanárok: Bíró György és Kisfaludi András.

4 Idesorolandó: Boóc Ádám, Darázs Lénárd, Fuglinszky Ádám, Katonáné Pehr Erika, Osztovits András, Pázmándi Kinga, Szeibert Orsolya.

5 Ilyenként emelhetô ki Kovács László és Zsohár András.

6 E körben nevesíthetô: Barta Géza, Boros Zsuzsa, Farkas Attila László, Gadó Gábor, Gál Judit, Havasi Péter, Kiss Mária, Komáromi Gábor, Makai Katalin, Molnár Ambrus, Murányi Katalin, Orosz Árpád, Petrik Béla, Petrik Ferenc, Pomeisl András, Sándor Tamás, Takáts Péter, Wellmann György.

7 A kontinentális civiljog fejlôdésére lásd Kecskés, 2009:545.

8 Az igazságszolgáltatás polgári kori reformjának briliáns összefoglalása olvasható Máthé Gábor alapmûvében. Lásd Máthé, 1982:239.

9 A hagyomány szerint Werbốczy 1504-ben kezdte el írni a Hármaskönyvet (Tripartitum) Alsópetényben, és 1514. október 18-án, a pesti/rákosmezei országgyúlésen mutatta be a rendeknek. Elsố (még a szerzô életében napvilágot látott) kiadása 1517-ben, Bécsben jelent meg latin nyelven Johann Singrienernél (Johannes Singrenius). Mivel az évszázadok során a cím olykor módosult, az elsố (eredeti) kiadás azt az alábbiakban adja meg: Werbốczy, 1517. Erre lásd Koi, 2016:5, 6. lábjegyzet.

10 A werbốczyánus jogi írók és múveik felsorolására lásd Koi, 2016:5-7.

11 Magyarország Magánjogi Törvénykönyve, 1928. A törvényjavaslat indokolásának csupán az elsố kötete jelent meg, a második (kötelmi és öröklési jogi) kötetnek az országgyúlési irományok, más anyagok közt sincs nyoma. Az elsô kötet: Indokolás Magyarország Magánjogi Törvénykönyvének Törvényjavaslatához I. Történeti áttekintés. A törvényjavaslat általános jellemzése. Bevezetô szabályok. Elsô rész: személyi és családi jog. Második rész: dologi jog. Az Mtj. német fordítása: Ungarns Privatgesetzbuch. Entwurf 1928. IM, Budapest, 1940, 678 o. Megjegyzendô, hogy 1852-ben az osztrák polgári törvénykönyv is hatályban volt.

12 A bolgár polgári jog fejlôdésére lásd Hamza, 2002:86-87, 208-210.

13 Csehi Zoltán, tanszékvezetô egyetemi docens (PPKE); Kemenes István ítélôtáblai kollégium- vezetô (Szeged); Kisfaludi András egyetemi tanár (ELTE); Kórös András tanácselnök, Legfelsôbb Bíróság; Lábady Tamás, ítélôtáblai elnök (Pécs); Menyhárd Attila tanszékvezetố egyetemi docens (ELTE); Székely László miniszteri biztos; Wellmann György kollégiumvezetô, Legfelsốbb Bíróság.

14 Harmathy Attila akadémikus, professor emeritus (ELTE); Kisfaludi András egyetemi tanár (ELTE); Lábady Tamás ítélôtáblai elnök (Pécs); Petrik Ferenc ny. kollégiumvezetô, Legfelsôbb Bíróság; Sárközy Tamás egyetemi tanár (BCE); Székely László miniszteri biztos; Weiss Emilia professor emeritus (ELTE); Zlinszky János professor emeritus (PPKE).

\section{FelHASZnÁlt irodAlom}

Hamza Gábor (2002): Az európai magánjog fejlődése. A modern magánjogi rendszerek kialakulása a római jogi hagyományok alapján. Nemzeti Tankönyvkiadó, Budapest.

Kecskés László (2009): A polgári jog fejlôdése a kontinentális Európa nagy jogrendszereiben. HVGOrac, Budapest.

Koi Gyula (2016): Államfogalom és az államról való gondolkodás (állameszme) a közjogi államtudományban hazánkban a 18-20. században. NKE, Budapest.

Máthé Gábor (1982): A magyar burzsoá igazságszolgáltatási szervezet kialakulása 1867-1875. Akadémiai Kiadó, Budapest.

Országgyúlés Képviselôházának irományai (1928): 500. szám törvényjavaslat. Magyarország Magánjogi Törvénykönyve. Váci kir. Országos Fegyintézet nyomdája, Budapest, https://library.hungaricana.hu/hu/view/OGYK_KI-1927_08/?p$\mathrm{g}=0$ \&layout $=1$.

Petrik Ferenc (szerk.) (2013): Polgári jog. Kommentár a gyakorlat számára I. (Harmadik kiadás), HVG-Orac, Budapest.

Werbốczy István (1517): Tripartitum opus iuris consuetudinary (!) inclyti regni Hungariae: Stephanum de Werbewcz personalis presentie (!) regie (!) maiestatis locum tenentem: accuratissime editum. Johannes Singrenius, Viennae Austriae, Octavo die Maii. 